\title{
Factors affecting Early Age Marriage in Dhankuta Municipality, Nepal
}

\author{
Sah RB, ${ }^{1 *}$ Gaurav $K,{ }^{1}$ Baral DD, ${ }^{1}$ Subedi L, ${ }^{1}$ Jha $N,{ }^{1}$ Pokharel PK ${ }^{1}$ \\ ${ }^{I}$ School of Public Health \& Community Medicine, B P Koirala Institute of Health Sciences, Dharan, Nepal
}

\author{
*Corresponding Author: \\ Dr Ram Bilakshan Sah \\ Associate Professor \\ School of Public Health \& Community Medicine \\ $B$ P Koirala Institute of Health Sciences \\ Dharan, Nepal \\ Email: bilaksah@Yahoo.com

\section{Citation} \\ Sah RB, Gaurav K, Baral DD, Subedi L, Jha N, Pokharel \\ PK. Factors affecting Early Age Marriage in Dhankuta \\ Municipality, Nepal. Nepal Journal of Medical Sciences \\ 2014;3(1):26-30.
}

\begin{abstract}
Background: Child marriage is a substantial barrier to social and economic development in Nepal, and a primary concern for women's health. Little evidence from Nepal is available regarding the ways in which early marriage may compromise young women's lives and their reproductive health and choices. The objectives of this study was to find out the factors associated with early age marriages in Dhankuta Municipality.

Methods: The cross-sectional study was conducted among the residents of Dhankuta municipality, Nepal; where 246 households were taken as subjects. Pretested semi-structured questionnaire was administered to the study subjects and face to face interview was conducted. Chi-square test was applied to find out the association between factors and age of marriages.
\end{abstract}

Results: Almost 53.3\% of women were married before age 18 years. Education of wife and husband, and economic status are found to be the important variables in explaining early age marriage. Prevalence of child marriage was higher in Hindu than in Buddhist and Christian women but the difference was not significant. Age of marriage was not significantly associated with contraceptive use. Unwanted pregnancies were higher in early age marriage. It was also seen that unwanted pregnancies was higher $(59.3 \%)$ than wanted pregnancies $(48.6 \%)$.

Conclusion: The findings of the study indicate that early age marriage was associated with low education and being poor.

Keywords: Early age marriage; factors; socio-economic status

\section{Background:}

Child marriage defined by UNICEF as marriage before 18 years of age is a reality for more than 60 million women worldwide. ${ }^{1}$ The practice has become increasingly recognised as a human rights violation ${ }^{2,3}$ and has decreased worldwide during the past 20 years. ${ }^{4}$ Nonetheless, child marriage remains pervasive in South Asia, where more than half of all child marriages occur. Previous data indicate that about $30-70 \%$ of women in Bangladesh, Nepal, India, and Pakistan were married before 18 years of age. ${ }^{1,5}$

Adolescent mothers are more likely to experience fistula, pregnancy complications, and death during childbirth than are older mothers. ${ }^{2,5,6}$ Such pregnancies have been consistently linked to increased risk of maternal and infant morbidity and mortality. ${ }^{1,2,6}$ The UN have prioritised maternal health, infant mortality, and women's empowerment with the inclusion of 
these issues in the Millennium Development Goals. ${ }^{7}$ This action has reinforced the urgent need to understand and reduce child marriage and its effect on maternal and child health, particularly in South Asia, where more than a third of all maternal and child deaths occur. ${ }^{8}$

Despite the pervasiveness and severe consequences, little empirical research has been published in the past decade about child marriage or the related public health effects. Therefore, the present study was chosen to find out the factors associated with early age marriages in Dhankuta Municipality.

\section{Methods:}

The cross-sectional study was conducted from $28^{\text {th }}$ March to $10^{\text {th }}$ April, 2013 among the residents of Dhankuta municipality in Eastern Nepal. Among 9 wards, the ward number four was randomly selected by lottery method in Dhankuta Municipality.

To represent the women for $29 \%$ early age marriage (NDHS, 2011) sample size calculated was 246. All the participants aged 15 to 49 years from the selected households were included in the study. Convenient purposive sampling technique was applied for data collection.

The independent variables were used in the analyses: age, religion, ethnicity, education, occupation, economic status, decision of marriage, use of contraception and wanted or unwanted pregnancies. The variables selected in this investigation are those that are frequently used for the analysis of early age marriage. All the independent variables were obtained from the section on participant's background characteristics.

A written permission was taken from concerned authority and an informed verbal consent was taken from the participants of the study. Those families which were available after three visits and willing to give verbal consents were included in the study. Pretested semi-structured questionnaire was administered to the study subjects in the presence of investigator and face to face interview was conducted.

The collected data was entered in MS Excel 2000. The analysis was done by using statistical software SPSS (Statistical Package for Social Science) 17.0 version. Chisquare test was applied to find out the association between factors and age of marriages. The probability of occurrence by chance is significant if $\mathrm{P}<0.05$ with $95 \%$ Confidence
Interval.

\section{Results:}

More than half of women were married before 18 years of age (table 1).

Table 1: Distribution of study population by sociodemographic characteristics with age of marriage

\begin{tabular}{|c|c|c|c|c|}
\hline Characteristics & $\begin{array}{c}\text { Below } 18 \\
\text { years }\end{array}$ & $\begin{array}{l}18 \text { years } \\
\& \text { above }\end{array}$ & Total & $\begin{array}{c}\text { P- } \\
\text { value }\end{array}$ \\
\hline \multicolumn{5}{|l|}{ Religion } \\
\hline Hindu & $123(54.2)$ & $104(45.8)$ & 227 & 0.311 \\
\hline Buddhist, Christian & $8(42.1)$ & $11(57.9)$ & 19 & \\
\hline \multicolumn{5}{|l|}{ Ethnicity } \\
\hline Brahmin/ Chhetri & $47(49.0)$ & $49(51.0)$ & 96 & 0.174 \\
\hline Janajati/ Kirati & $68(54.4)$ & $57(45.6)$ & 125 & \\
\hline $\begin{array}{l}\text { Others (Dalit/ } \\
\text { Terai caste) }\end{array}$ & $16(64.0)$ & $9(36.0)$ & 25 & \\
\hline \multicolumn{5}{|l|}{ Education of wife } \\
\hline Illiterate & $27(69.2)$ & $12(30.8)$ & 39 & 0.001 \\
\hline Below SLC* & $58(58.6)$ & $41(41.4)$ & 99 & \\
\hline SLC and above & $46(42.6)$ & $62(57.4)$ & 108 & \\
\hline \multicolumn{5}{|l|}{ Education of husband } \\
\hline Illiterate & $7(77.8)$ & $2(22.2)$ & 9 & 0.006 \\
\hline Below SLC & $62(60.8)$ & $40(39.2)$ & 102 & \\
\hline SLC and above & $62(45.9)$ & $73(54.1)$ & 135 & \\
\hline \multicolumn{5}{|l|}{ Occupation of female } \\
\hline Housewife & $98(57.0)$ & $74(43.0)$ & 172 & 0.140 \\
\hline Farmer & $9(53.0)$ & $8(47.0)$ & 17 & \\
\hline Business & $16(40.0)$ & $24(60.0)$ & 40 & \\
\hline Service & $2(25.0)$ & $6(75.0)$ & 8 & \\
\hline $\begin{array}{l}\text { Others (Abroad, } \\
\text { labor, unemployed) }\end{array}$ & $6(66.7)$ & $3(33.3)$ & 9 & \\
\hline \multicolumn{5}{|l|}{ Occupation of male } \\
\hline Farmer & $8(50.0)$ & $8(50.0)$ & 16 & 0.208 \\
\hline Business & $16(44.4)$ & $20(55.6)$ & 36 & \\
\hline Service & $53(52.5)$ & $48(47.5)$ & 101 & \\
\hline $\begin{array}{l}\text { Others (Abroad, } \\
\text { labor, unemployed) }\end{array}$ & $54(58.1)$ & $39(41.9)$ & 93 & \\
\hline \multicolumn{5}{|l|}{ Economic status } \\
\hline Below poverty & $76(75.2)$ & $25(24.8)$ & 101 & $<0.001$ \\
\hline $\operatorname{line}(<1.25 \mathrm{US} \$)$ & $56(38.6)$ & $89(61.4)$ & 145 & \\
\hline $\begin{array}{l}\text { Above poverty } \\
\text { line }(\geq 1.25 \text { US } \$)\end{array}$ & & & & \\
\hline Total & $131(53.3)$ & $115(46.7)$ & 246 & \\
\hline
\end{tabular}

*SLC: School Leaving Certificate

The highest prevalence of child marriage was recorded in those who were illiterate and below poverty line $(\mathrm{P}<0.05)$. Prevalence of child marriage was higher in Hindu than in Buddhist and Christian women but the difference was 
not significant. Child marriage was also more common in women with illiterate husbands than those with more educated husbands $(\mathrm{p}<0.05)$.

All the participants of this study had used contraceptives. Child marriage was not significantly associated with use of contraception and wanted or unwanted pregnancies (table 2).

Table 2: Association between selected variables with age of marriage

\begin{tabular}{|ccccc|}
\hline Characteristics & $\begin{array}{c}\text { Below 18 } \\
\text { years }\end{array}$ & $\begin{array}{c}\mathbf{1 8} \text { years } \\
\text { \& above }\end{array}$ & Total & $\begin{array}{c}\text { P- } \\
\text { value }\end{array}$ \\
\hline $\begin{array}{c}\text { Decision of marriage } \\
\text { Self }\end{array}$ & $59(57.3)$ & $44(42.7)$ & 103 & 0.282 \\
Family & $72(50.3)$ & $71(49.7)$ & 143 & \\
$\begin{array}{c}\text { Use contraception } \\
\text { before } 1^{\text {st }} \text { pregnancy }\end{array}$ & & & & \\
$\quad$ Condom & $7(63.6)$ & $4(36.4)$ & 11 & 0.560 \\
$\quad$ Oral pills & $4(50.0)$ & $4(50.0)$ & 8 & \\
$\quad$ Depo & $120(52.9)$ & $107(47.1)$ & 227 & \\
$1^{\text {st }}$ pregnancy & & & & \\
$\quad$ Wanted & $67(48.6)$ & $71(51.4)$ & 138 & 0.095 \\
$\quad$ Unwanted & $64(59.3)$ & $44(40.7)$ & 108 & \\
Total & $131(53.3)$ & $115(46.7)$ & 246 & \\
\hline
\end{tabular}

\section{Discussion:}

Through, Nepal is a small country with 23.2 million populations. Due to limited resources, high population growth (2.7 percent per year) has become a serious challenge to economic development. High total fertility rate (TFR) is the influence of early age initiation of child bearing process and continuation till the last of reproductive age compound with more frequent birth. The early age initiation of child bearing process due to physiological immaturity leads to pregnancy related complications to mother and child as well as more risk of low birth weight. Short spaced born are also at higher risk of low birth weight and due to frequent birth nutritional status of mother deteriorate and forms a viscous cycle. $^{9}$

Early marriages, defined this analysis as marriages before age 18 for females and before age 20 for males, are common among women in Nepal. ${ }^{10}$ Early marriage has been prevalent in Nepal. Census data show that $75 \%$ of women aged 15 19 years were married in 1971 . Very early marriages have become less common in recent years but still remain high. The 1991 census data show that $46 \%$ of women aged $15-19$ years were married. ${ }^{11}$

Our study showed that more than half of women were married before the legal age of 18 years. A study conducted by Raj A et al also showed that nearly half of Indian women were married before the legal age of 18 years. ${ }^{12}$ Child marriages are rare in Indonesia which may be due to nearly universal availability of primary level education. ${ }^{10}$

Prevalence of child marriage was higher in Hindu than Buddhist and Christian women but the difference was not significant. But other study conducted in India showed Prevalence of child marriage was significantly higher in Hindu than those of other religions. ${ }^{12}$ Religion has been found to have a significant role in determining age at marriage, particularly for girls..$^{13,14}$

Dalit and Terai caste have higher prevalence of child marriage than other ethnic groups but the difference was not significant. But previous studies have found a relationship between ethnicity and age at marriage both in developed and developing countries. ${ }^{13,15}$ Kobrin and Goldscheider (1978) also reported ethnic differences in age at marriage and marriage patterns in the United States of America. ${ }^{15}$

The highest prevalence of child marriage was recorded in women, those who were illiterate $(\mathrm{P}<0.05)$. The relationship between education and age at marriage is well established from previous studies. ${ }^{13,16,17}$ Adedokun (1999) found in a study in Nigeria that the duration of schooling has strong correlation with age at marriage. ${ }^{13}$ Young women aspiring to college education are likely to delay marriage. ${ }^{16}$ Females with no education or very low level of education in less developed countries who tend to marry very early. ${ }^{10}$

The highest prevalence of child marriage was recorded in women with illiterate or less educated husband $(\mathrm{P}<0.05)$. A study conducted by Raj A et al in India also showed higher prevalence of child marriage in women with less educated husbands than those with more educated husbands $(\mathrm{p}<0.0001)$ : child marriage was reported by $77.1 \%$ of women whose husbands had no formal education and 33.7\% of those whose husbands had some higher education. ${ }^{12}$ Education of husband also showed the similar pattern as education of the wife. ${ }^{18}$

This study showed that economic status significantly associated with age at marriage.

In many societies the economic status of the family is also significant in determining the age at which people marry. Axinn and Thornton (1992) stated that social and economic conditions in the parental home affect the likelihood of marriage of young women. ${ }^{16}$ Dahal et al. (1993) observed from Nepal that girls experience delayed marriage where their parents have greater landholdings than their potential 
parents-in-law. ${ }^{19}$ Economic independence of women, as well as the economic status of the family, has a significant effect on the age at which women marry. Some scholars confirm that increasing economic independence of women is largely responsible for the delay in marrying ${ }^{20}$ and a lack of independence accelerates the transition to marriage. ${ }^{21}$

All the participants of this study used contraceptives. But study conducted in India showed in married women, no contraceptive use before first childbirth was highly pervasive. Almost a fifth of women had had a child in the first year of marriage, and more than one in six women had had three or more childbirths. More than one in eight women had been sterilised, but of those not sterilised, $77.2 \%$ reported no present contraception use. ${ }^{12}$ Child marriage was not significantly associated with unwanted pregnancies. But study conducted by Raj A et al showed child marriage was significantly associated with one or more unwanted pregnancies. $^{12}$

\section{Conclusion:}

The findings of the study indicate that early age marriage was associated with low education and being poor. These factors should be considered in designing new strategies to combat rapid population growth and reduce both fertility and mortality in the country. Efforts to improve the status of women through their increased participation in education should be encouraged.

\section{Acknowledgement:}

We would like to thank to MBBS (2010 Batch) students who helped us during study period. Our gratitude and sincere thank to participants of Dhankuta Municipality without their support study was not possible and the person who helped us in every way during study period.

\section{Conflict of interest: None}

\section{References:}

1. UNICEF. Progress for children: a world fit for children statistical review. Protecting against abuse, exploitation and violence: child marriage. Available at; http://www. unicef.org/ progressforchildren/2007n6/ index_41848. htm (Accessed June 16, 2013).

2. UNICEF. Early marriage: child spouses (March, 2001). Available at; http://www. Unicef-icdc.org/ publications/ pdf/digest7e.pdf (Accessed June 16, 2013).

3. Saardchom N, Lemaire J. Causes of increasing ages at marriage an international regression study. Marriage Fam Rev 2005; 37:73-97. http://dx.doi.org/10.1300/J002v37n03 05

4. Indian Government, Law Commission of India. Proposal to amend the prohibition of child marriage act, 2006 and other allied laws (report number 205; February, 2008). Available at; http://lawcommissionofindia. nic. in/reports/report205.pdf (Accessed June 16, 2013).

5. International Center for Research on Women. New insights on preventing child marriage:a global analysis of factors and programs (April, 2007). Available at; http:// www.icrw.Org /docs/2007-new-insightspreventingchild-marriage.pdf (Accessed June 16, 2013).

6. UNFPA.State of world population 2005. Child marriage fact sheet. Available at; http://www.unfpa. Org/ swp/2005/presskit/factsheets/facts_child_marriage.htm (Accessed June 16, 2013).

7. UN. UN Millennium Development Goals. Available at; http://www.un.org/ millennium goals. (Accessed June 16, 2013)

8. Bhutta ZA, Gupta I, de'Silva H. Maternal and child health: is South Asia ready for change. BMJ 2004;328:816-9. http://dx.doi.org/10.1136/bmj.328.7443.816

9. Central Bureau of Statistics (CBS) 2001, Population Census (National Report) Kathmandu: Central Bureau of statistics.

10. Choe MK, Thapa S, Achmad S. Early marriage and child bearing in Indonesia and Nepal. East-west center working papers. 2001;108-15.

11. Pradhan A, Aryal RH, Regmi G, et al. Nepal Family Health Survey 1996. Kathmandu, Nepal and Calverton, Maryland: Ministry of Health [Nepal], New ERA, and Macro International, Inc.

12. Raj A, Saggurti N, Balaiah D, et al. Prevalence of child marriage and its effect on fertility and fertility control outcomes of young women in India: a cross sectional, observational study. The lancet 2009;373:1883-9. http://dx.doi.org/10.1016/S0140-6736(09)60246-4 
13. Adedokun A. Perspectives on African Traditional Architecture and Planning. SEDEC Publishers, Lagos, Nigeria, 1999.

14. Grenier G, Bloom DE, Howland DJ. An analysis of the first marriage patterns of Canadian women. Discussion Paper 85-3. Cambridge MA: Harvard University,1985.

15. Kobrin FE, Goldscheider C. The Ethnic Factor in Family Structure and Mobility, Cambridge MA: Ballinger Publishing Co, 1978.

16. Axinn WG, Thornton A. The influence of parental resources on the timing of the transition to marriage. Social Science Research 1992; 21:261-85. http://dx.doi.org/10.1016/0049-089X(92)90008-5

17. Bates LM, Maselko J, Schuler SR. Women's education and the timing of marriage and childbearing in the next generation: evidence from rural Bangladesh. Studies in
Family Planning 2007; 38:101-12.

http://dx.doi.org/10.1111/j.1728-4465.2007.00121.x

18. Paudel IS, Singh SP, Jha N, et al. High risk Pregnancies and its correlates among the women of Eastern Nepal. Indian J Prev Soc Med 2008; 39:133-9.

19. Dahal DR, Fricke T, Thornton A. The family context of marriage timing in Nepal. Ethnology 1993;32:305-23. http://dx.doi.org/10.2307/3773455

20. Preston SH, Richards AT. The Influence of Women's Work Opportunities on Marriage Rates. Demography 1975;12:209-22.

http://dx.doi.org/10.2307/2060761

21. Lichter DT, McLaughlin DK, Kephart G, et al. Race and the Retreat from Marriage: A Shortage of Marriageable Men. American Sociological Review 1992; 57:781-99. http://dx.doi.org/10.2307/2096123 